\title{
ABSTRACTS IN ENGLISH
}

Educatio 30 (3), pp. 567-571 (2021)

DOI: $10.1556 / 2063.30 .2021 .3 .17$

\section{THE 30TH ANNIVERSARY OF THE JOURNAL EDUCATIO ${ }^{\circledR}$ - STUDIES}

\section{TAMÁS KOZMA EVALUATING GOVERNMENT POLICIES, A REVIEW OF THIRTY YEARS}

The purpose of this writing is twofold. On the one hand, it is an introduction to further studies of the present publication of Educatio ${ }^{\oplus}$. On the other hand, it is a look back at the Journal's issues focused on education policy evaluation compiled every four years between 1992 and 2018. These thematic issues can be read both on paper and online. What cannot be read is their history of origin. The present article is about the idea of education policy evaluation, the circumstances of organising, the debates on editing, and the excitements around their appearance. The writing covers three decades of the Journal, and is structured by the four-year periods of its outcoming. Our goal was not to write a complete history of Educatio ${ }^{\oplus}$. Instead, to highlight the background, the conflicts, and the atmosphere of evaluating government policies. Thus, the writing contributes to both the present issue and the career path of Educatio ${ }^{\oplus}$

Keywords: policy analysis, Journal Educatio ${ }^{\varpi}$, newspaper history

\section{IVÁN BAJOMI}

\section{SHOULD THE PUBLIC EDUCATION COUNCIL BE OF APPOINTMENTS OR DELEGATES?}

In my study based on new documents found in connection with the beginnings of the National Council for Public Education (OKT), I first point out that some earlier patterns (mainly Prussian and French) played an important role in the formation of the body set up in 1871, four years after the Austro-Hungarian compromise put an end to the 18-year-long military dictatorship and absolutist rule over Hungary. The way in which foreign bodies were organized took on a hybrid character in some periods, as the members, or at least some of them, were not selected from above, unlike the medieval secret royal councils, but the principle of delegation also played a role. Proposals from a county school council and some teachers' associations may have played a role in the fact that the OKT was organized in a hybrid way in the years after its formation, i.e. not only persons selected from above, but also delegated members, but later principle has been pushed into the background. Finally, I also point out in my writing that in several later phases of the history of Hungarian education councils, the conflict between the principles of delegation and top-down appointment and the application of hybrid solutions was observed. 
Keywords: National Educational Council, national educational council patterns, elected or appointed members, actors for educational self-government, hybrid educational-councils

KATALIN FORRAY R. CHANGES OF THE ROMA IMAGE IN EDUCATIO, 1991-2021

The study reviews policies related to the education of the Roma population and their outcomes since the change of regime. It presents the Minority Law and its subsequent amendments to the schooling of Romani and Beas languages. He emphasizes the importance of Gandhi High School and the Department of Romology of the University of Pécs. It characterizes the low level of education of the Roma population by presenting case studies. Finally, it describes the possibilities of support by describing two helpful interventions. Most importantly, that the extreme backwardness of the Roma, previously considered general, has declined significantly.

Keywords: Romani population in Hungary, Romani languages, schooling, programmes for undereducated

\section{ILDIKÓ HRUBOS}

\section{THE UNIVERSITY OF THE 21ST CENTURY - THE DESTINY OF} A TOPIC INTENDED FOR A HUNDRED YEARS, AFTER 15 YEARS

The study in 2006 introduced the main processes that defined the situation of higher education systems at the turn of the millennium. The central theme of the study was the Bologna-reform. The present work is intended to call attention to the developments that were not expected in the first years of this century, and those that occurred faster than expected or took a different direction. From the aspect of the Bologna-reform, it became clear that from the beginning it has been struggling with the problem that the founders were guided by two different primary concepts: the concept of a federal and confederal Europe. The vision of the "revival" of the European university was soon faced with the counteraction of globalization progressing faster than expected, and its new challenges. In 2006 nobody expected this rapid spread of digitization in the entirety of the economy and society, and within that in higher education. Today it appears that directly serving society is becoming a dominant mission of 21 st century universities (higher education), fulfilling which will again fundamentally transform the tasks and positions of the actors in the sector.

Keywords: European higher education reform, globalization, digitization, missions of higher education

\section{PÉTER TIBOR NAGY}

SEVEN POTENTIAL RESEARCHES ABOUT THE SOCIAL SCIENCES

Continuing the author's 2007 Educatio paper "Four Possible Researches on Academic Staff", the study outlines a research plan based on three sources and three different 
types of relationships between them. The first research would analyzed the positions (exeminer, leader, employed positions). The second research examines the effects of multipositionality, distinguishing the non-scientific positions within academic workplace, non-scientific positions outside academic workplace, scientific positions outside academic workplace The third research would analyze the world of journals, as in the other cases, distinguishing between the management of journals, the use of journals for publication, the manifesto debate, the lectorship activity, and the editing of thematic issues. In the "reflections" block, we would conduct research on the main function of quotations and critiques on positioning the author in the scientific space. According to the initial hypothesis of co-authorship, there may be three main motivations for this: working together, expressing a covenant relationship, and expressing a master-student relationship. In the chapter of "civil societies" we describe scientific societies in the duality of managers and simple "users", but - contrary to the world of journals - here the non controlled oralism of conferences plays a role, which also opens the way for an outside circle. Types of power effort not directly related to scientific production are the distribution of money, the sharing of medals, and the control over data.

Keywords: sociology of sciences, sociology of higher education, sociology of elites, methodology

\section{ISTVÁN POLÓNYI}

\section{TO LOOK IN THE MIRROR. THE PLACE OF THE EDUCATIO JOURNAL AMONG THE HUNGARIAN EDUCATIONAL SCIENSES JOURNALS}

The purpose of this study is to examine some of the scientific metrics of the journal Educatio on the occasion of its 30th anniversary. The article analyzes some of the content and quantitative features of the journal and its measurable weight, significance and impact in the field of educational research, comparing it with the other three major Hungarian pedagogical journals: Magyar Peadgógia (Hungarian Pedagogy), Iskolakultúra (School Culture) and Uj Pedagógiai Szemle (the New Pedagogical Review). In addition, the study examines how much the teaching and research members of the most significant workshops in Hungarian education publish in Educatio and how much they refer to the journal's writings.

Keywords: citation characteristics of the journal Educatio, publications of members of educational workshops

\section{GÉZA SÁSKA}

\section{TWO PERIODS OF EQUALITY AND SEGREGATION EDUCATION POLICY IN HUNGARY}

The study describes the anti-middle-class movements to increase social equality from the mid-1930s, and the unifying measures of the authoritarian and totalitarian state until the early 1960s in the education policy. For aiming at the social peace more and more concessions was made to the middle class. It caused gradually increased the distance between social strata in terms of educational attainment. Firstly the social inequality 
appeared within (educational) institutions, and later between institutions. In the mid1980s, and more after the change of regime, the reorganization of school and school management based on the idea of self-government abolished the institutinal system of social equalization in the public education system, which made possible for the middleclass parents and teachers the creating of elit schools.

Keywords: trends of equality and segregation, middle class opposition and consequences, school autonomy, segregation or segregation-enhancing

\section{RESEARCH ACTIVITIES}

\section{IDA DRINGÓ-HORVÁTH - JUDIT T. NAGY - ANDREA WEBER OPPORTUNITIES FOR DEVELOPING FACULTY MEMBERS' DIGITAL TEACHING COMPETENCE IN HIGHER EDUCATION}

The article focuses on the significance of developing the competence of digital pedagogy. Following that, we will propose a complex plan for institutional educational development, the elements of which (preliminary needs and competence analysis, the development process itself, and feedback, i.e. measuring the efficacy of development) will be able to successfully guarantee, by building on each other in an intertwined fashion, the systematic and reflective ICT development of teachers in higher education. Apart from thoroughly introducing and giving a rationale for each element, the study will also highlight the results of the first pilot run and, by drawing conclusions from the pilot's experiences, plans for improvement.

Keywords digital competence, higher education, educational professional development

\section{ANNAMÁRIA KAZAI-ÓNODI \\ ONLINE OR TRADITIONAL EDUCATION? STUDENT QUESTIONNAIRE SURVEY ABOUT THEIR SATISFACTION IN AN EXTRAORDINARY SEMESTER OF EDUCATION}

Struggle against the coronavirus epidemic meant a huge challenge and a driving force for development. We had to switch to online education. Our student questionnaire survey at the Corvinus University of Budapest, which contains more than 500 answers, provides an insight into the extraordinary period of the first half of 2020/2021. We started with a mixed education and then switched to full online education. We present the factors that led to the fact that students' satisfaction with the subject did not decrease, and what was the biggest challenge for the students. The key message of our survey is, that more than $80 \%$ of the students would choose the traditional weekly seminars.

Keywords: tertiary education, epidemic, online education, student opinion 


\section{ANITA KÉRI \\ LONGITUDINAL QUALITATIVE STUDY OF FOREIGN STUDENTS' SATISFACTION AND LOYALTY AT THE UNIVERSITY OF SZEGED}

The internationalization of higher education has long been at the centre of research interest. Therefore, the opinion of foreign students and the study of Hungarian higher education institutions' service quality are researched widely. The aim of the current study is to shed light on the changes in foreign student expectations and satisfaction and to examine their loyalty with a longitudinal panel interview series over three years. Research results show that foreign student expectations and satisfaction change with time and loyalty can appear towards the institution and the foreign study experience, too.

Keywords: higher education, internationalization, expectations, satisfaction, loyalty

\section{ÉVA KISS - GYÖRGY VARGA \\ CO-OPERATIONS OF HUNGARIAN HIGHER EDUCATION AND COMPANIES FROM THE VIEWPOINT OF INDUSTRY 4.0}

This paper investigates how Hungarian higher education institutions have responded to revolutionary changes in industry reflecting government measures and corporate partnerships. Based on the literature and educational institutional data, as well as a company case study, it can be concluded that in recent years significant progress has been made in the training of professionals in higher education in order to be adjusted to the challenges of Industry 4.0. This was made partly possible by the deepening of state policies and, in particular, cooperation with German companies. In the long term, all these can have an impact on the spatial processes of the Hungarian industry, in addition to economic and social consequences.

Keywords: Industry 4.0, higher education, corporate partnership, mechatronics engineer training, dual training

\section{GABRIELLA HORVÁTH-CSIKÓS - TÍMEA JUHÁSZ THE LABOUR MARKET REQUIREMENT OF SOFT AND HARD SKILLS}

The aim of the present study is to examine whether soft or hard skills are seen as the strongest requirement in the current labour market. The results of the research showed that some soft skills (e.g. flexibility, communication, teamwork) are almost more strongly expected than hard skills (e.g. professional knowledge). These results basically indicate that expectations of soft and hard skills are less interrelated and that employees perceive employers as valuing these skills as non-systemic, closely related skills. Our results also show that self-reported levels of soft and hard skills are strongly correlated with gender, age and educational attainment of the respondent.

Keywords: soft skills, hard skills, employees, labour market

A cikk a Creative Commons Attribution 4.0 International License (https://creativecommons.org/licenses/ by-nc/4.0/) feltételei szerint publikált Open Access közlemény, melynek szellemében a cikk bármilyen médiumban szabadon felhasználható, megosztható és újraközölhető, feltéve, hogy az eredeti szerző és a közlés helye, illetve a CC License linkje és az esetlegesen végrehajtott módosítások feltüntetésre kerülnek. 